\title{
Regional Seismicity before the Matsushiro Earthquake Swarm
}

\author{
by \\ Yoshinori Arakawa \\ Matsushiro Seismological Observatory \\ and \\ Shigeji Suyehiro \\ Meteorological Research Institute, Tokyo \\ (Received December 12, 1969)
}

\begin{abstract}
The regional seismicity before the Matsushiro Earthquake Swarm was studied for large, small and micro-earthquakes. Findings are as follows.

1) Past major earthquakes and swarms near Matsushiro occurred outside the swarm region, and the swarm region had been left unaffected for many years.

2) For a period of 8 years prior to the swarm, the region where the swarm initially started was comparatively quiet, and a higher activity was found in the surrounding region where the swarm was to extend in its later stages.

3) A small swarm activity occurred from April 1963 to June 1964 with several rises and falls. These earthquakes, however, did not occur in the initial swarm region. The Matsushiro swarm started after this activity had once diminished.

4) The " $m$ " value was smaller $(m=1.65)$ before the swarm and increased up to $m=2.02$ after the start of the swarm.

5) The regional seismicity before the swarm showed a pattern that is usually found for large earthquakes, i.e. the regional seismicity is abnormally low for a certain period of time before the occurrence of a large earthquake.
\end{abstract}

\section{Introduction}

The Matsushiro Earthquake Swarm started on Aug. 3, 1965 and still shows a trail activity as of September, 1969. The World-wide Standard Seismograph of 
short period at the Matsushiro Seismological Observatory $\left(V_{\max }: 100,000\right)$ recorded 703,279 earthquakes from the start through September 1969, and 62,557 of these were perceptible at the observatory. The total seismic energy released from the start to February 1967 was estimated to be $1.57 \times 10^{21}$ ergs, and this energy is equivalent to that of one earthquake of $M=6.3$ (Party for Seismographic Observation of Matsushiro Earthquakes and the Seismometrical Section of Earthquake Research Institute, 1967). An earthquake of $M=6.3$ may not be very large. But against the regional background activity near Matsushiro, which is only a few small perceptible earthquakes per year, an energy release of $1.57 \times 10^{21} \mathrm{ergs}$ in one and a half years is outstanding, no matter whether the energy was released by one earthquake or by many earthquakes.

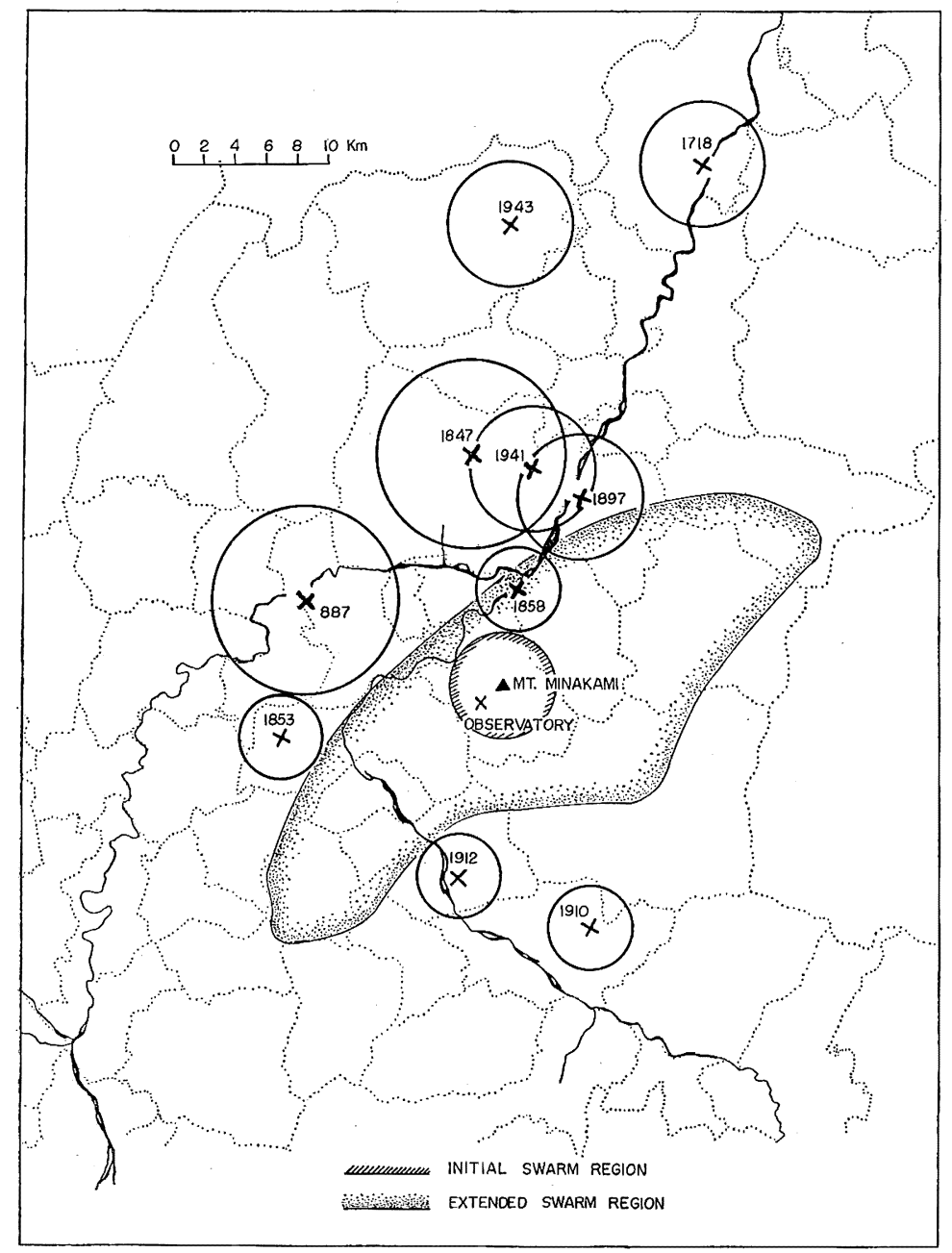

Fig. 1. Epicenter and magnitude of the major historical earthquakes in the basin of Nagano and the region of the Matsushiro earthquake swarm. Large circle: $M=7.0$, Medium circle: $M=6.0 \sim 6.9$, Small circle: $M=5.0 \sim 5.9$. 
Recently several authors studied regional seismicity before large earthquakes and concluded that large earthquakes are apt to take place in a region where the seismic activity has been abnormally low for a certain period of time (S. A. FEDOTOV, 1965 ; K. Goto and Y. SaKaI, 1965; W. Inouye, 1965; T. Utsu, 1968; K. Mogi, 1969). What about the pre-swarm seismicity in the Matsushiro region?

Fortunately, the Matsushiro Seismological Observatory equipped with sensitive seismographs is located in the region, where the initial swarm activity started, and observations of micro-earthquakes were also repeated at the observatory (T. AsADA, S. SuYehiro and K. AKamatsu, 1958; S. Suyehiro, T. Asada and S. Ohtake, 1964). In this paper, local earthquakes of $S-P$ less than 3 sec were mainly studied, which were recorded by the short-period Benioff Seismograph in a period of 8 years prior to the start of the swarm, together with other available data.

\section{Past major earthquakes and swarms in the region}

Fig. 1 shows epicenters and magnitudes of the major historical earthquakes in the basin of Nagano and region of the Matsushiro earthquake swarm (T. MryauchI,

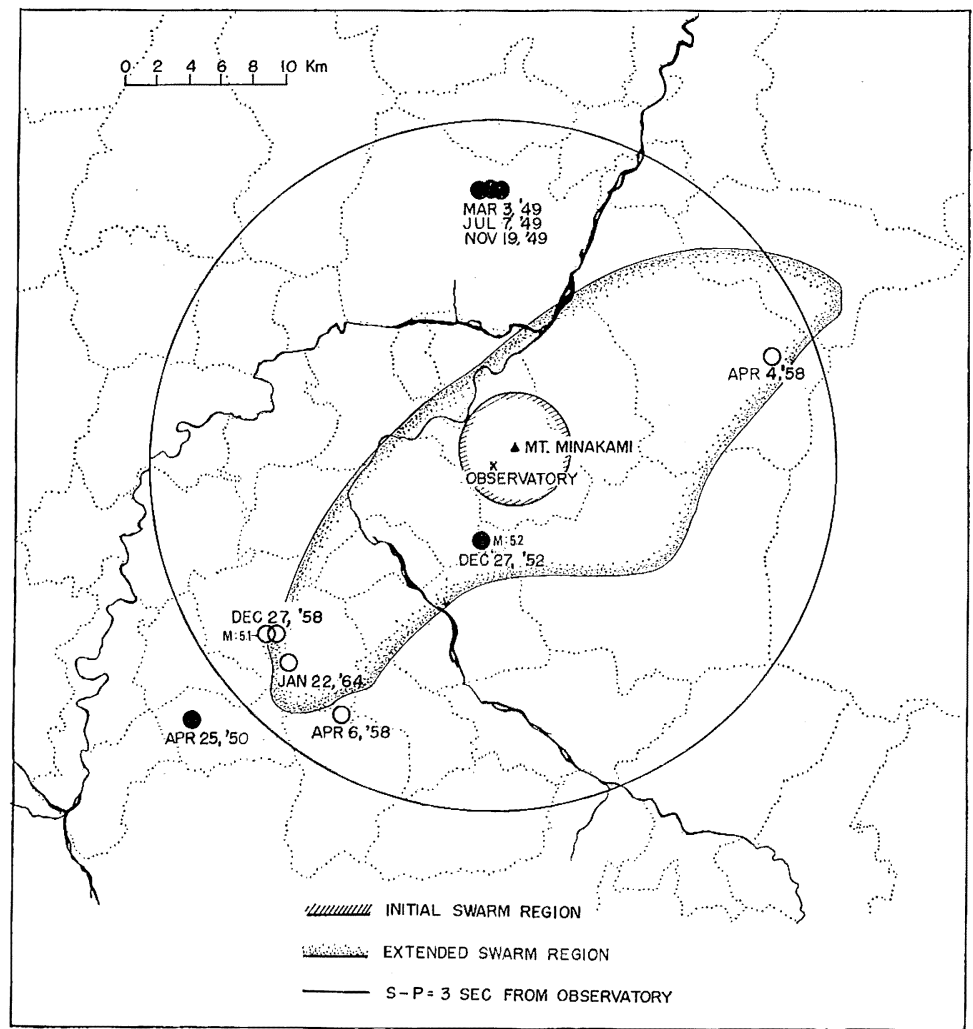

Fig. 2. Epicenter of perceptible earthquakes since 1949 that were located by JMA network and the region of the Matsushiro earthquake swarm. 
Table 1. List of perceptible earthquakes of $S-P=3.0 \mathrm{sec}$ at the Matsushiro Seismological Observatory.

\begin{tabular}{|c|c|c|c|c|c|c|c|}
\hline Year & Dat & & Time & $S-P$ & $\begin{array}{l}\text { Epicenter } \\
\text { direction }\end{array}$ & $\begin{array}{l}\text { Intensity at the } \\
\text { observatory }\end{array}$ & Remarks \\
\hline \multirow[t]{5}{*}{1949} & Mar. & 3 & 0146 & & & 0 & $36.7 \mathrm{~N}, 138.2 \mathrm{E}$, near Nagano \\
\hline & Jul. & 7 & 1018 & & & 0 & $36.7 \mathrm{~N}, 138.2 \mathrm{E}$, near Nagano \\
\hline & Oct. & 4 & 1934 & 2. & & 0 & near Nagano \\
\hline & Nov. & 19 & 0008 & & & 0 & $36.7 \mathrm{~N}, 138.2 \mathrm{E}$, near Nagano \\
\hline & Nov. & 26 & 0337 & 2.4 & & 0 & near Nagano \\
\hline \multirow[t]{9}{*}{1950} & Feb. & 2 & 2305 & 3. & & 0 & near Nagano \\
\hline & Feb. & 2 & 2313 & & & 0 & near Nagano \\
\hline & Feb. & 2 & 2316 & 3. & & 0 & near Nagano \\
\hline & Mar. & 27 & 1026 & & & 0 & near Nagano \\
\hline & Mar. & 27 & 1112 & & & 0 & near Nagano \\
\hline & Apr. & 5 & 1623 & & & 0 & near Nagano \\
\hline & Apr. & 25 & 1905 & 2.2 & & II & $\begin{array}{l}36.4 \mathrm{~N}, 138.0 \mathrm{E} \text {, near Matsu- } \\
\text { moto }\end{array}$ \\
\hline & Oct. & 12 & 2115 & 1.4 & S W & I & near Matsushiro \\
\hline & Nov. & 11 & 0922 & 1.1 & & 0 & near Yashiro \\
\hline \multirow[t]{9}{*}{1951} & Jan. & 28 & 0933 & & & 0 & near Nagano \\
\hline & Mar. & 31 & 0712 & 2.3 & & 0 & near Susaka \\
\hline & Jun. & 22 & 1903 & 2.1 & & 0 & near Yashiro \\
\hline & Jul. & 21 & 1848 & 1.1 & & 0 & near Yashiro \\
\hline & Aug. & 6 & 1713 & & & 0 & near Toyosato \\
\hline & Aug. & 11 & 2139 & 0.9 & & 0 & near Matsushiro \\
\hline & Oct. & 11 & 1755 & & & 0 & near Sakaki \\
\hline & Oct. & 12 & 0525 & & & 0 & near Sakaki \\
\hline & Nov. & 3 & 0522 & 2.2 & & 0 & near Nagano \\
\hline \multirow[t]{4}{*}{1952} & Apr. & 13 & 0428 & 1.4 & & 0 & \\
\hline & Jun. & 27 & 2035 & & & 0 & near Muroga \\
\hline & Jul. & 17 & 0732 & 1.2 & & 0 & near Nagano \\
\hline & Dec. & 27 & 1459 & 1.3 & S W & III & $\begin{array}{l}36.5 \mathrm{~N}, \quad 138.2 \mathrm{E}, \quad \mathrm{M}=5.2 \\
\text { northern Nagano Pref. }\end{array}$ \\
\hline \multirow[t]{8}{*}{1953} & Feb. & 1 & 1547 & 2.3 & & 0 & near Yashiro \\
\hline & May & 7 & 0152 & 3.0 & & 0 & near Nagano \\
\hline & May & 24 & 0546 & 1.8 & & I & northern Nagano Pref. \\
\hline & Jul. & 6 & $03^{\pi} 35$ & 1.1 & & I & near Matsushiro \\
\hline & Jul. & 6 & 0338 & 1.2 & & I & near Matsushiro \\
\hline & Oct. & 1 & 2220 & & & 0 & near Nagano \\
\hline & Oct. & 2 & 0009 & 2. & & 0 & northern Nagano Pref. \\
\hline & Oct. & 2 & 0020 & & & 0 & near Nagano \\
\hline \multirow[t]{2}{*}{1954} & Sep. & 10 & 0456 & & & 0 & near Nagano \\
\hline & Dec. & 2 & 0526 & 2. & & 0 & near Nagano \\
\hline \multirow[t]{2}{*}{1955} & Jul. & 1 & 0028 & 3.0 & & 0 & near Oomachi \\
\hline & Aug. & 7 & 1250 & 2.1 & & 0 & near Nagano \\
\hline
\end{tabular}

(Continued) 
(Continued)

\begin{tabular}{|c|c|c|c|c|c|c|}
\hline Year & Date & $\begin{array}{l}\text { Time } \\
\mathrm{h} \mathrm{m}\end{array}$ & $S-P$ & $\begin{array}{r}\text { Epicenter } \\
\text { direction }\end{array}$ & $\begin{array}{c}\text { Intensity at the } \\
\text { observatory }\end{array}$ & Remarks \\
\hline \multirow[t]{2}{*}{1955} & Oct. & 0721 & 3.0 & & 0 & near Nagano \\
\hline & Oct. 24 & 0340 & 1.3 & $\mathrm{NE}$ & I & northern Nagano Pref. \\
\hline 1956 & Jan. 27 & 1504 & & S W & $\mathrm{I}$ & northern Nagano Pref. \\
\hline \multirow[t]{5}{*}{1957} & Feb. 27 & 0842 & 2.2 & & 0 & near Nagano \\
\hline & Feb. 27 & 1038 & 2.9 & & 0 & near Nagano \\
\hline & Apr. 10 & 0454 & 1.6 & & 0 & near Nagano \\
\hline & Jul. 14 & 0943 & & & 0 & northern Nagano Pref. \\
\hline & Aug. 17 & 1501 & 1.9 & & 0 & near Nagano \\
\hline \multirow[t]{8}{*}{1958} & Mar. 31 & 1648 & 1.7 & $\mathrm{NE}$ & 0 & near Susaka \\
\hline & Apr. 4 & 1313 & 2.4 & NE & II & $36.6 \mathrm{~N}, 138.4 \mathrm{E}$ \\
\hline & Apr. 6 & 0623 & 2.4 & S W & II & $36.4 \mathrm{~N}, 138.1 \mathrm{E}$ \\
\hline & Oct. 28 & 1656 & & S W & $\mathrm{I}$ & near Matsushiro \\
\hline & Nov. 19 & 1720 & & & 0 & near Ueda \\
\hline & Nov. 24 & 0822 & 2. & S W & I & northern Nagano Pref. \\
\hline & Dec. 27 & 0855 & & S W & II & $36.5 \mathrm{~N}, 138.1 \mathrm{E}, \mathrm{M}=5.1$ \\
\hline & Dec. 27 & 1403 & 2.8 & S W & 0 & $36.5 \mathrm{~N}, 138.1 \mathrm{E}$ \\
\hline \multirow[t]{3}{*}{1959} & Sep. & 0138 & 3. & & 0 & northern Nagano Pref. \\
\hline & Oct. & 1627 & 2.4 & $\mathrm{~S} \mathrm{~W}$ & I & northern Nagano Pref. \\
\hline & Oct. & 1636 & & & 0 & near Nagano \\
\hline \multirow[t]{2}{*}{1961} & Aug. 26 & 1517 & & & 0 & near Matsushiro \\
\hline & Dec. 22 & 0359 & 0.8 & $\mathrm{~S} \mathrm{~W}$ & 0 & near Matsushiro \\
\hline 1962 & Feb. 10 & 1035 & 2.9 & S W & 0 & \\
\hline \multirow[t]{3}{*}{1963} & Sep. 8 & 0752 & 1.3 & $\mathrm{NE}$ & I & northern Nagano Pref. \\
\hline & Sep. 18 & 1415 & & & 0 & near Toyoshina \\
\hline & Dec. 5 & 0947 & & & 0 & near Ueda \\
\hline \multirow[t]{3}{*}{1964} & Jan. 22 & 2302 & 2.7 & $\mathrm{~S} \mathrm{~W}$ & I & $36.4 \mathrm{~N}, 138.1 \mathrm{E}$ \\
\hline & May 26 & 0536 & 3.0 & & 0 & \\
\hline & Sep. 20 & 0424 & 1: 3 & & 0 & near Matsushiro \\
\hline
\end{tabular}

1968). Most earthquakes occurred along the Chikuma River, and none of them occurred near the initial swarm region, only one having occurred near the margin of the extended swarm region.

In addition to major earthquakes, earthquake swarms occurred many times in this region (H. SEKIYA, 1968). Again, no earthquake swarms have ever been found in the region of the Matsushiro swarm at least since 1870.

Table 1 gives perceptible earthquakes of less than 3 sec in $S-P$ since 1949, and the epicenters of comparatively large earthquakes among them, which were located by JMA network, were plotted in Fig. 2. Once again, no epicenters were found near the initial swarm region. 
The pre-swarm seismicity of comparatively large earthquakes and swarms indicates that the area near the initial swarm region had been very quiet and the surrounding region, in contrast, had been active.

\section{New material}

To study the pre-swarm seismicity more precisely, instrumental data of local earthquakes of $S-P=3 \mathrm{sec}$ at the observatory were examined for the period of 8 years prior to the start of the swarm (see Fig. 2). The seismograms by the short-period Benioff $\left(T_{\text {seismo }}=1.0 \mathrm{sec}, T_{\mathrm{galv}}=0.2 \mathrm{sec}, V_{\max }=100,000\right)$ were used to search small local earthquakes, and those by the short-period vertical seismograph ( $T_{\mathrm{sismo}}=1.0 \mathrm{sec}$, $\left.T_{\text {galv }}=0.8 \mathrm{sec}, V_{\max }=32,000\right)$ were used to measure the maximum amplitudes. In the said period, 1,100 of such local earthquakes were found, most of them being very small earthquakes and 20 of them being small perceptible earthquakes.

In August 1956, a high sensitivity observation (overall sensitivity $=10^{-7} \mathrm{kine} / \mathrm{mm}$ for a frequency band of 10 to $200 \mathrm{cps}$ ) was first made at the observatory. In December 1963 and January 1964, a similar observation was repeated by a small tripartite net to study the distribution and frequency of occurrence of micro-earthquakes. The results thus obtained were also used in this study.

\section{Pre-swarm seismicity of small earthquakes}

\section{a) General}

Fig. 3 shows the monthly frequency of occurrence of small earthquakes of $S-P \leqq 3$ sec at the observatory. The mean monthly frequency is about 10 , but there occurred many times small earthquake swarms. The first one occurred in December 1958 about 17 kilometers to the southwest of the observatory, and is considered to have been aftershocks of the earthquake of $M=5.1$ of December 27, 1958.

From April 3 to 5, 1963, about 200 small earthquakes of 1.8 to 2.1 sec in $S-P$ occurred again about 15 kilometers to the southwest of the observatory. In Septem-

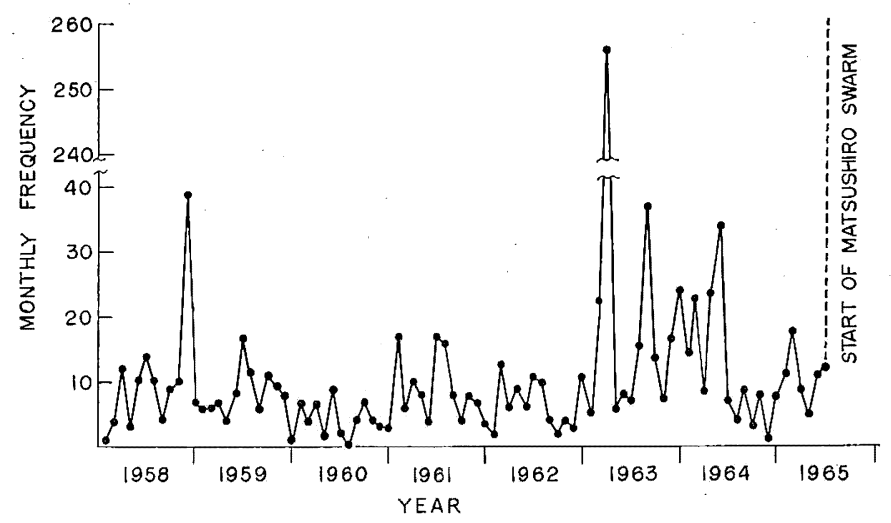

Fig. 3. Monthly frequency of occurrence of small earthquakes of $S-P \leqq 3.0$ sec recorded at the Matsushiro Seismological Observatory. 
ber 1963, earthquakes of 1.3 to $2.0 \mathrm{sec}$ in $S-P$ occurred and in June 1964 those of about $3 \mathrm{sec}$ occurred in a group with the direction of initial motion in NE. This activity, which started from April 1963 and continued with rises and falls, died down in June 1964, and the Matsushiro swarm started after one year.

As in the past major earthquakes and swarms, the small swarms in the 8 years before the Matsushiro swarm, did not affect the initial region and the innermost part of the extended region of the Matsushiro swarm.

b) Distribution of $S-P$ time

$S-P$ time could be measured for about $90 \%$ of recorded local earthquakes by short-period Benioff, and the annual frequency distribution is shown in Fig. 4. Most $S-P$ times are from 1.6 to 3.0 sec, whereas the Matsushiro swarm started initially within several kilometers of Mt. Minakami with $S-P$ time from 0.6 to 1.0 sec as shown in Fig. 5. The seismic activity of small earthquakes before the swarm had been very low in the region where the swarm broke out. On the contrary, the preswarm activity was comparatively high in the surrounding region, into which the Matsushiro swarm extended in its later stage. This surrounding region still shows some trailing activity as of September 1969, when the swarm has almost died down in the initial region around Mt. Minakami.

The distribution of $S-P$ times of much smaller earthquakes $(M=-1 \sim+1)$ based on the observation for 12 days in December 1963 and January 1964 is shown in Fig. 6 (b), and the epicenters determined by the tripartite net are shown in Fig. 7.

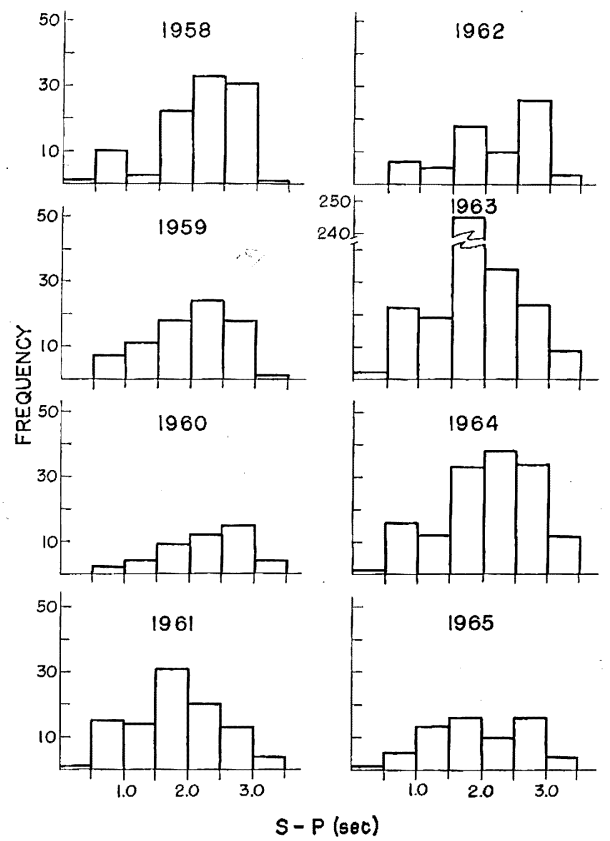

Fig. 4. Annual frequency distribution of $S-P$ time of small earthquakes recorded at the Matsushiro Seismological Observatory. 


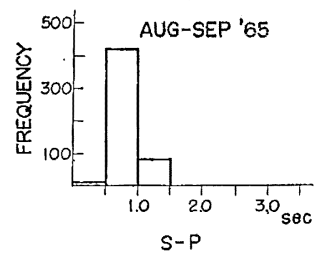

Fig. 5. Frequency distribution of $S-P$ time of the Matsushiro earthquake swarm in its initial stage.

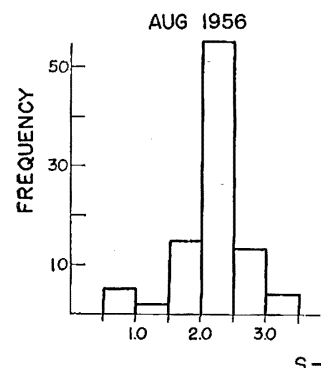

(a)
DEC 1963 - JAN 1964

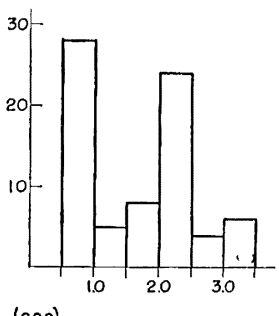

(b)

Fig. 6. Frequency distribution of $S-P$ time of micro-earthquakes near the Matsushiro Seismological Observatory.

(a) August 1956, (b) December 1963 and January 1964.

Two peaks are seen in Fig. 6 (b) from 0.6 to $1.0 \mathrm{sec}$ and from 2.1 to $2.5 \mathrm{sec}$. In Fig. 7, however, most epicenters of $S-P$ of 0.6 to $1.0 \mathrm{sec}$ are found outside the initial swarm region. In August 1956, the first observation of high sensitivity was made, and at this time $S-P$ times of 2.1 to 2.5 sec predominated with much fewer earthquakes of $S-P$ of 0.6 to $1.0 \mathrm{sec}$ as shown in Fig. 6 (a).

According to T. AsADA and I. KARAKAMA (1967), who made a high sensitivity observation at the very early stage of the Matsushiro swarm in August 1965 at the foot of Mt. Minakami, earthquakes of $S-P$ of 0.7 to $1.1 \mathrm{sec}$ broke out abruptly in an extremely large number and the micro-earthquake activity outside the circle of $3 \mathrm{~km}$ in radius from Mt. Minakami appreciably decreased.

\section{c). Discussion}

Past major and swarm earthquakes described in Section 2, small earthquakes that occurred near Matsushiro in 8 years before the swarm and micro-earthquakes observed in 1956 and 1964 were located mainly in the surrounding region of the Matsushiro swarm. The swarm region extended outward in its later stage into the surrounding region where a comparatively high seismicity had been found before the start of the swarm. Such a seismicity associated with the Matsushiro swarm agrees well with the statement made by K. MoGI (1969): "In the period (several to twenty years) just before a great event, the area where the great event occurs is abnormally calm and its surrounding wide area becomes markedly active (the foreshock activity in a broad sense). With the great event, the above-mentioned doughnut pattern of 


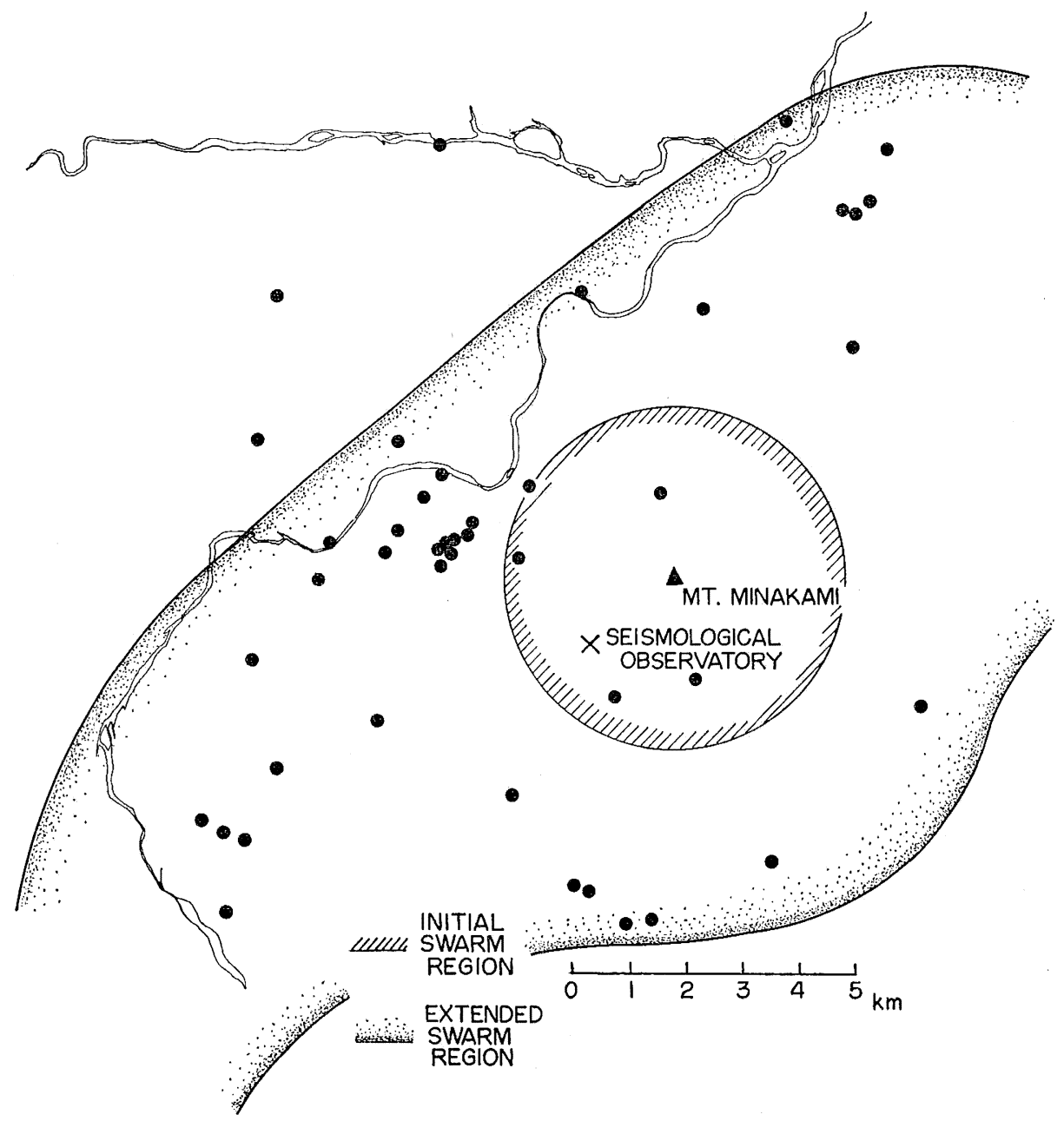

Fig. 7. Epicenter of micro-earthquakes located by a tripartite net at the Matsushiro Seismological Observatory in December 1963 and January 1964.

the seismic activity disappears and then the area in and near the focal region of the great earthquake becomes active (the aftershock activity in a broad sense)." The activity of 1963 to 1964 may be considered as foreshocks in a broad sense that occurred in the surrounding region.

\section{Ishimoto-Iida's coefficient, " $m$ "}

The " $m$ " value, which indicates the relation between frequency of occurrence and magnitude, was determined by least squares from amplitudes by the short-period vertical seismograph and is shown annually in Fig. 8. Its change in time is shown in Fig. 9. A comparatively large value, $m=2.27$, was given to 1963 when a large number of small earthquakes occurred in swarm. Except for this year, a decreasing 


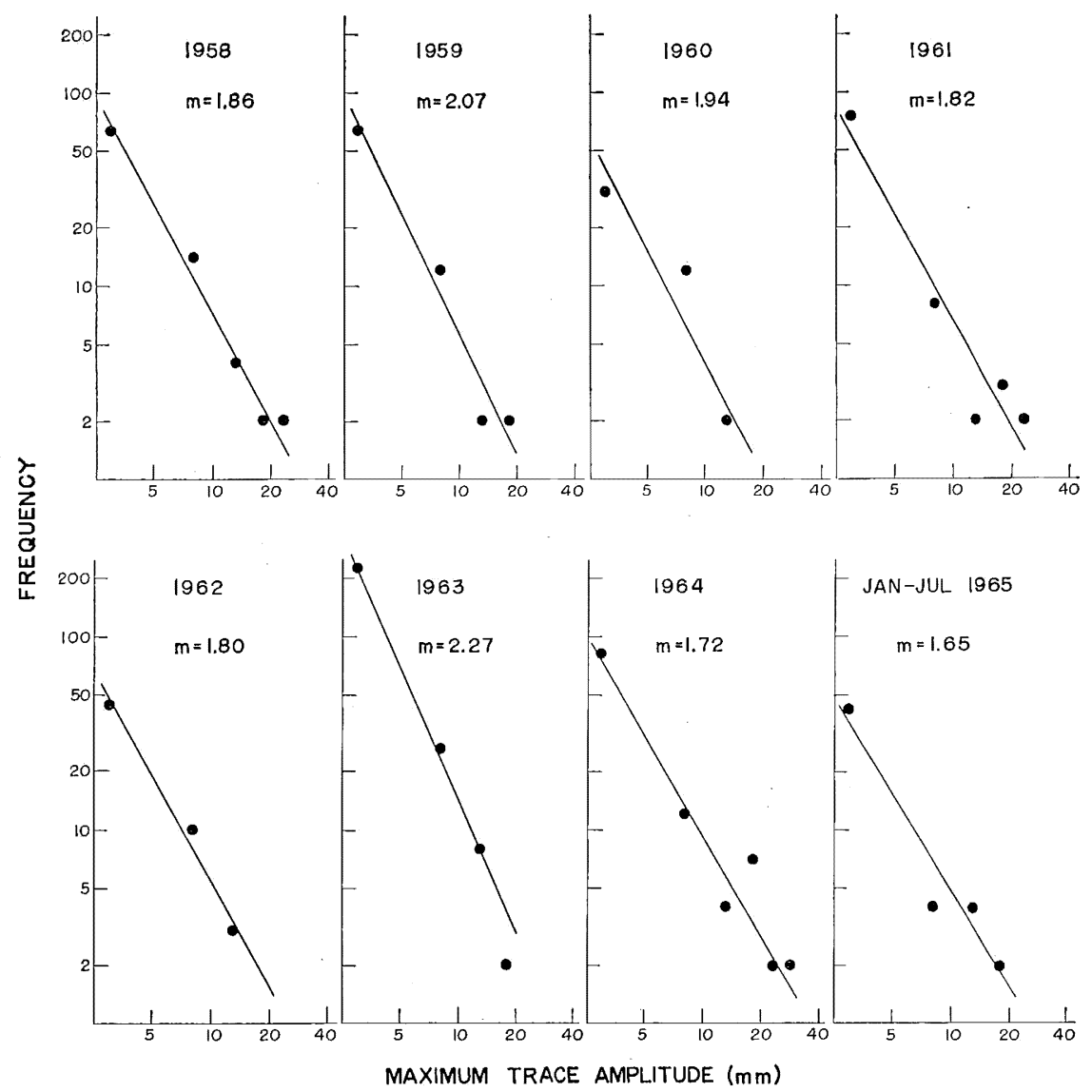

Fig. 8. Relation between maximum trace amplitude by the shortperiod vertical seismograph and frequency of occurrence.

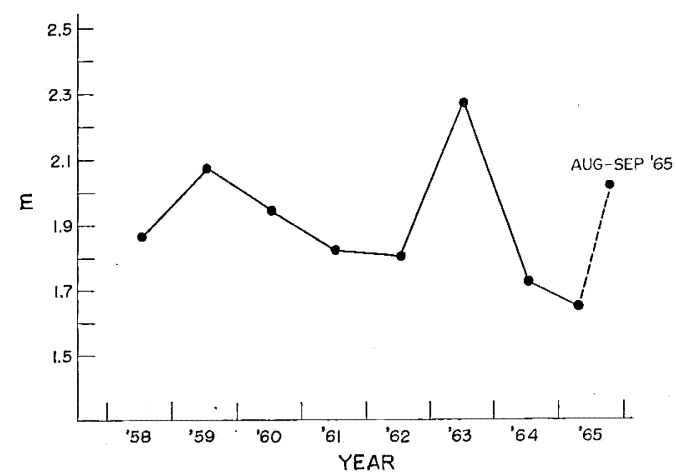

Fig. 9. Change of " $m$ " value in time. 
tendency is seen toward $m=1.65$ for the period of January to July 1965. Almost the same value, $m=1.66$, was also given for the whole year from August 1964 to July 1965. With the start of the Matsushiro swarm, the " $m$ " value jumped up to 2.02 .

\section{Conclusion}

1) Past major earthquakes and swarms near Matsushiro occurred outside the swarm region, the swarm region having' been left unaffected for many years.

2) For a period of 8 years before the Matsushiro swarm, the region where the swarm initially started was comparatively quiet, and a higher activity was found in the surrounding region where the swarm was to extend in its later stage.

3) A small swarm activity occurred from April 1963 to June 1964 with several rises and falls. These earthquakes, however, did not occur in the initial swarm region. The Matsushiro swarm started after this activity had subsided.

4) The " $m$ " value was smaller $(m=1.65)$ before the swarm and increased up to $m=2.02$ after the start of the swarm.

5) The regional seismicity before the Matsushiro Earthquake Swarm showed a pattern that is usually found for large earthquakes, i.e. the regional seismicity is abnormally low for a certain period of time before the occurrence of a large earthquake.

Acknowledgement-This research was supported by the jonit research program of the Meteorological Research Institute.

\section{References}

Asada, T., S. Suyehiro and K. Akamatsu, 1958: Observation of near-by micro-earthquakes occurring in the vicinity of Matsushiro, Japan. Zisin II, 11, 7-19.

FEDotov, S. A., 1965: Regularities of the distribution of strong earthquakes in Kamchatka, the Kuril Islands and northeastern Japan. Akad. Nauk SSSR Inst., Fiziki Zemli, No. 36 (203), 66-93.

GoTo, K. and Y. SAKaI, 1965: Orally presented at a meeting of the Seismological Society of Japan.

INOUYE, W., 1965: On the seismicity in the epicentral region and its neighbourhood before the Niigata Earthquake. Kenshinjiho, 29, 139-144.

Miyauchi, T., 1968: Historical earthquakes which occurred around Matsushiro. Tech. Report JMA, 62, 240-247.

MoGr, K., 1969: Some features of recent seismic activity in and near Japan (2)'. Activity before and after great earthquakes. Bull. Earthq. Res. Inst., 47, 395-417.

Party for Seismographic Observation of Matsushiro Earthquakes and the Seismometrical Section of Earthquake Research Institute, 1967: Matsushiro earthquakes observed with a temporary seismographic network. Part 4, Bull. Earthq. Res. Inst., 45, 887-917.

SeniYA, H., 1968: Earthquake swarms in the northern Nagano Prefecture. Tech. Report JMA, 62, 247-249.

Suyehiro, S., T. AsAda and M. OHTAKe, 1964: Foreshocks and aftershocks accompanying a perceptible earthquake in central Japan. Pap. Met. Geophys., 15, 71-88. 
UTsU, T., 1968: Seismic activity in Hokkaido and its vicinity. Geophy. Bull. Hokkaido Univ., 20, $51-75$.

\title{
松代群発地震発生前の同地方における地震活動について
}

\author{
荒川義則, 末広重二 \\ （地震観測所）（気象研究所）
}

松代群発地震発生前の同地方に和ける地震活動の状態を大，中，小および微小地震について調べたとこ ろ, 次のことが明かとなった。

1）松代附近の過去の大地震と群発地震はすべて今回の群発地域以外で発生している。つまり今回の群発は 空白として残された場所に発生した。

2）群発前 8 年間の小地震と微小地震の活動状態を見ると, 初期の群発発生地域では活動度が低く, 逆に後 に群発発生地域の拡がった周辺地域で高かった。

3）小群発活動が1963年 4 月から1964年 6 月にかけて何回か発生している。しかし発生地域は初期の松代群 発発生地域と異なる。松代群発はこの活動が一旦止んでから開始された。

4) 石本・飯田の $m$ 值は群発以前には小さく $(m=1.65)$, 群発の開始と共に $m=2.02$ に増えた。

5）以上松代群発発生前の地震活動の状態は何人かの研究者によって言われている大地震前の活動状態によ く似ている。即ち，大地震の発生前の地震活動はある期間異常に低くなり，逆に周辺地域で活潑になるとい う事実である。 